\title{
Atlantic sturgeon Acipenser oxyrinchus and alien sturgeon species in Polish waters: can biometric analysis assist species discrimination and restoration?
}

\author{
SŁAWOMIR KESZKA, ${ }^{1}$ REMIGIUSZ PANICZ ${ }^{2}$ \\ ${ }^{1}$ Department of Aquaculture, Faculty of Food Sciences and Fisheries, West Pomeranian University of Technology, ul. K. Królewicza 4, \\ 71-550 Szczecin, Poland, e-mail: skeszka@zut.edu.pl. \\ 2 Department of Meat Technology, Faculty of Food Sciences and Fisheries, West Pomeranian University of Technology, \\ ul. K. Królewicza 4, 71-550 Szczecin, Poland, e-mail: rpanicz@zut.edu.pl.
}

Keywords bycatch, countable and measurable characters, multidimensional analysis, restocking, species identification

Abstract Biometric character analyses were conducted on Atlantic sturgeon Acipenser oxyrinchus, a species included in a re-establishment programme in the Baltic Sea basin. The study sought to identify measurable and countable characters most useful for distinguishing $A$. oxyrinchus from three alien species found in open waters of Poland: Acipenser baerii, Acipenser gueldenstaedtii, and Acipenser stellatus. Measurable characters that contributed most to discrimination included preorbital distance, eye diameter, ventral fin base to anal fin base, and postorbital distance. Among countable characters, the number of lateral scutes made the greatest contribution. The data from the present study may be used to supplement existing systematic keys and lay the foundations for creating a catalogue or atlas of popular species and interspecific hybrids of sturgeon, including their complete systematic determination.

\section{Jesiotr ostronosy Acipenser oxyrinchus oraz obce gatunki jesiotrów w wodach Polski: czy analiza biometryczna uzupełni identyfikację i restytucję gatunków?}

Słowa kluczowe analiza dyskryminacyjna, cechy biometryczne, identyfikacja gatunków, przyłów, restytucja gatunku

Streszczenie W niniejszej pracy przedstawiono wyniki analizy cech biometrycznych osobników jesiotra ostronosego Acipenser oxyrhinchus oxyrhinchus, gatunku objętego restytucją w basenie Morza Bałtyckiego. Przy wykorzystaniu technik aglomeracyjnych podjęto próbę wyjaśnienia, które z cech mierzalnych i policzalnych mają największą przydatność przy odróżnianiu Acipenser oxyrinchus oxyrinchus od trzech gatunków obcych, łowionych w wodach otwartych Polski, tj. jesiotra syberyjskiego (Acipenser baerii), rosyjskiego (Acipenser gueldenstaedtii) oraz siewrugi (Acipenser stellatus). Wyniki analiz wykazały, że największy udział w dyskryminacji na podstawie cech mierzalnych miały: długość rostrum (R), odległość między płetwami V i A (VA) oraz przestrzeń zaoczna (OP), natomiast wśród cech policzalnych była to liczba tarczek bocznych (SL). Wyniki uzyskane w niniejszej pracy wzbogacają aktualnie 
stosowane klucze do identyfikacji gatunków jesiotrów oraz mogą stanowić podstawę do opracowania katalogu bądź atlasu powszechnie występujących jesiotrowatych jak i ich hybryd międzygatunkowych.

\section{Introduction}

During the interwar period, when Poland's borders differed from the present and included the river Dniester and tributaries of the Danube river, Polish ichthyofauna included four species of Acipenser: Atlantic sturgeon Acipenser sturio (L. 1758) also known as the common sturgeon, the sterlet Acipenser ruthenus (L. 1758), the starry sturgeon Acipenser stellatus (Pallas, 1771), and the rare, ship sturgeon Acipenser nudiventris (Lovetsky, 1828; Kulmatycki, 1919, 1922, 1932, 1933; Starkiewicz, 1922). Numbers of $A$. sturio in Polish waters were already in decline in 1908-1910 (Grabda, 1971) and earlier along some stretches of the Vistula River (Sasorski, 1922), while, in the Oder River, it was a rare species even at the beginning of the 20th century (Kulmatycki, 1921). The last specimens of A. sturio in Polish waters were collected from the Vistula in the mid-1960s (Żelechowska, 1964).

Many years later, DNA studies of museum specimens revealed that a species similar to A. sturio, the Atlantic sturgeon Acipenser oxyrinchus (Mitchill, 1815), existed for 800 years in the Baltic Sea catchment area, and which, being able to better adapt to changing climatic conditions, supplanted $A$. sturio (Ludwig et al., 2002). Thus A. oxyrinchus, generally regarded as extinct in the Baltic Sea (Kolman et al., 2011a, b), has been included in the re-establishment plan. Using fish from the St. John River in Canada, stocking has been conducted since 2004 in locations where the species was recorded in the past: the Drawa, a tributary of the Oder (70,000 individuals) and the Drwęca, a tributary of the Vistula (51,000 individuals). An agreement between the Inland Fisheries Institute in Olsztyn and the Leibnitz Institute of freshwater Ecology and Inland Fisheries in Berlin has allowed the introduction of juvenile A. oxyrinchus to the rivers (Kolman et al., 2008).

Alien sturgeon species are appearing with increasing frequency in European waters, especially the Siberian sturgeon Acipenser baerii (Brandt, 1869) and the Russian sturgeon Acipenser gueldenstaedtii (Brandt, Ratzeberg, 1833) that are escapees from fish farms (Nabiałek, 1974; Filipiak, 1996; Elvira, Almodovar, 1997; Keszka, Stepanowska, 1997; Keszka et al., 2011). Individuals are often observed after periods of high water, especially near rivers supplying fish farms (Maury-Brachet et al., 2008). The occurrence of alien sturgeon in the natural environment is a highly controversial issue, especially in connection with the programme being undertaken for restocking $A$. oxyrinchus. Interspecific competition from alien species, disease transfer, and potential risk of hybridization also hinder attempts at restoring the species, especially with the increasing abundance of the alien species (Kempter et al., 2009; Gessner et al., 1999, 2010).

A necessary prerequisite for the success of sturgeon restoration is identification of exotic species and their elimination according to national regulations, and, if required, adjusting international codes and guidelines (Gessner et al., 2010). The identification of Acipenser species is problematic because of similarities among species due to high plasticity of biometric characters (Ruban, Sokolov, 1986; Guénette et al., 1993; Ruban, Panaiotidi, 1994; Paaver, 1997). Correct identification is also complicated by individual plasticity and human interference through the creation of hybrids (Loy et al., 1997). The aim of the present study was to conduct biometric analysis of $A$. oxyrinchus and compare data with that reported for A. gueldenstaedtii, A. baerii, and $A$. stellatus, as well as to use multidimensional analysis to select diagnostic characters useful for rapid identification of sturgeon in bycatch. 


\section{Material and methods}

Fifty dead juvenile specimens of $A$. oxyrinchus were collected from seine fishers in three

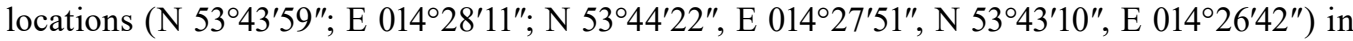
the Szczecin Lagoon near the town of Stepnica, from 21 May to 9 June 2008. The fish, some of which were tagged, originated from German stocking (Gessner et al., 2008) undertaken as part of a species restoration plan (Figure 1). Specimens were frozen using the method proposed by Keszka and Krzykawski (2008). Measurements were taken with calipers of $0.01 \mathrm{~mm}$ accuracy according to figure published by Kempter et al. (2013). Masses of individuals were measured with electronic scales with $0.01 \mathrm{~g}$ accuracy. Twenty-one measurable and five countable biometric characters were compared with characters of

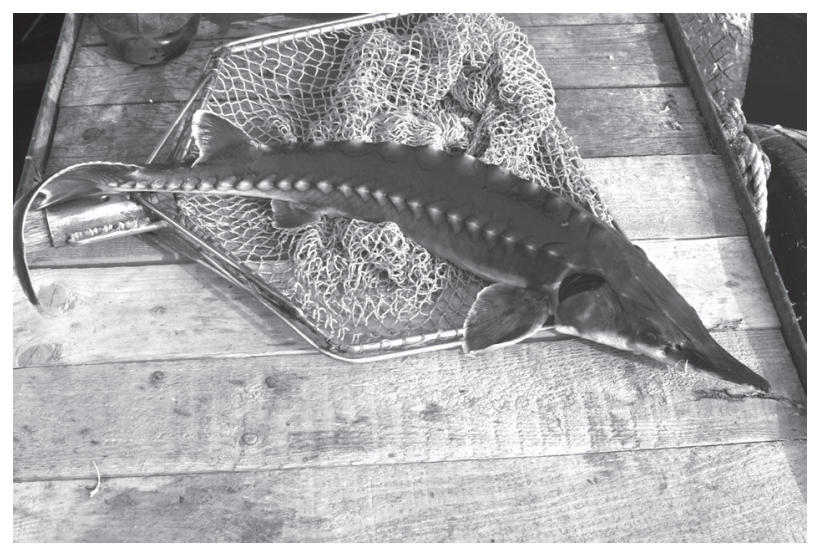

Figure 1. Acipenser oxyrinchus collected from the Szczecin Lagoon

Source: fhoto by S. Keszka.

A. baerii $(\mathrm{n}=336)$, A. gueldenstaedtii $(\mathrm{n}=99)$, and A. stellatus $(\mathrm{n}=69)($ Keszka, 2000; Keszka, Raczyński, 2006). Information on measurable characters for these 3 species were published by Keszka and Raczyński (2006), Keszka and Krzykawski (2008), Keszka et al. (2009). All individuals of alien species originated from warm water aquaculture systems in Nowe Czarnowo and Gryfino (NW Poland). Biometric characters of the studied species are given in Table 1.

Table 1. Biometric data for four sturgeon species

\begin{tabular}{|c|c|c|c|c|c|c|c|}
\hline \multirow{2}{*}{ Species } & \multirow{2}{*}{$\begin{array}{l}\text { Location/number } \\
\text { of specimens (n) }\end{array}$} & \multicolumn{3}{|c|}{$L_{\mathrm{T}}[\mathrm{mm}]$} & \multicolumn{3}{|c|}{ Mass [g] } \\
\hline & & $\min$ & $\max$ & mean & $\min$ & $\max$ & mean \\
\hline $\begin{array}{l}\text { Acipenser } \\
\text { oxyrinchus }\end{array}$ & $\begin{array}{l}\text { Roztoka Odrzańska } \\
\text { - Stepnica }(50)\end{array}$ & 209.8 & 680.00 & 351.39 & 31.0 & $1,122.7$ & 202.49 \\
\hline Acipenser baerii & $\begin{array}{l}\text { Cage culture } \\
\text { - Nowe Czarnowo (276) }\end{array}$ & 300.5 & 690.00 & 334.90 & 50.0 & $1,245.0$ & 274.20 \\
\hline $\begin{array}{l}\text { Acipenser } \\
\text { gueldenstadtii }\end{array}$ & $\begin{array}{l}\text { Cage culture } \\
\text { - Nowe Czarnowo (334) }\end{array}$ & 230.0 & 29.09 & 27.07 & 34.0 & 207.0 & 112.89 \\
\hline Acipenser stellatus & Cage culture - Gryfino (69) & 235.0 & 390.00 & 327.55 & 21.9 & 137.0 & 67.43 \\
\hline
\end{tabular}


Statistical analysis was performed using Statistica 10.1. Measurable and countable characters were summarized calculating minimum and maximum values, arithmetic mean, and standard deviation.

Per cent of total length $\left(L_{\mathrm{T}}\right)$ of measurable characters and absolute values for countable characters were used for conducting stepwise discriminant analysis and canonical discriminant analysis. Results were analysed taking into consideration the classification matrix and values of standardized coefficients for canonical variables and visualized as scatter plots of canonical scores.

\section{Results}

\section{Measurable Characters}

Length and mass were comparable for all specimens (Table 1). Measurable characters of $A$. oxyrinchus presented as absolute values $(\mathrm{mm})$ and as per cent calculated with respect to total length $\left(L_{\mathrm{T}}\right)$ are presented in Table 2 . Among the five countable characters, standard deviation for the number of dorsal scutes and the number of ventral scutes were the lowest and therefore similar to the mean value (Table 3).

Table 2. Measurable characters of the Acipenser oxyrinchus given as absolute values and as per cent total length $L_{\mathrm{T}}$

\begin{tabular}{|c|c|c|c|c|c|c|c|c|}
\hline \multirow{2}{*}{ Symbol and character description } & \multicolumn{4}{|c|}{ Value $[\mathrm{mm}]$} & \multicolumn{4}{|c|}{ Value $[\% \mathrm{Lt}]$} \\
\hline & $\min$ & $\max$ & mean & sd & $\min$ & $\max$ & mean & $\mathrm{sd}$ \\
\hline 1 & 2 & 3 & 4 & 5 & 6 & 7 & 8 & 9 \\
\hline$L_{\mathrm{T}}-$ Total length & 209.80 & 680.00 & 351.39 & 121.48 & & & & \\
\hline$L_{\mathrm{F}}-$ Fork length (Smitt's length) & 178.70 & 580.00 & 301.86 & 100.27 & 79.41 & 154.30 & 86.65 & 90.99 \\
\hline$L_{\mathrm{S}}-$ Standard length & 166.30 & 545.00 & 284.41 & 96.74 & 75.30 & 147.66 & 81.45 & 90.67 \\
\hline $\mathrm{C}$ - Length of head & 56.60 & 161.20 & 91.20 & 26.80 & 23.14 & 44.92 & 26.48 & 30.04 \\
\hline $\mathrm{R}$ - Preorbital distance (length of snout) & 26.40 & 86.20 & 47.87 & 14.44 & 11.13 & 23.44 & 13.88 & 10.67 \\
\hline $\mathrm{O}$ - Horizontal eye diameter & 50.20 & 11.70 & 70.22 & 10.69 & 10.58 & 30.32 & 20.14 & 00.31 \\
\hline $\mathrm{OP}$ - Postorbital distance & 22.60 & 65.20 & 36.02 & 11.27 & 90.46 & 18.98 & 10.41 & 10.32 \\
\hline HCo - Head depth (at centre of eye) & 13.40 & 37.50 & 20.72 & 50.86 & 50.21 & 10.25 & 60.05 & 00.77 \\
\hline HC - Head depth (at nape) & 18.90 & 55.40 & 31.31 & 90.79 & 60.29 & 14.26 & 90.05 & 00.99 \\
\hline $\mathrm{H}$ - Maximum body depth & 21.20 & 72.40 & 38.85 & 13.13 & 80.18 & 20.41 & 11.18 & 10.62 \\
\hline 1D - Length of dorsal fin & 12.70 & 43.10 & 22.92 & 70.97 & 50.43 & 12.79 & 60.56 & 00.99 \\
\hline Hd - Depth of dorsal fin & 12.80 & 51.70 & 22.91 & 80.41 & 50.39 & 11.19 & 60.54 & 00.88 \\
\hline $\mathrm{aD}$ - Predorsal dostance & 132.00 & 418.40 & 220.48 & 72.60 & 60.02 & 85.04 & 63.16 & 30.71 \\
\hline poD - postdorsal distance & 11.30 & 51.70 & 23.97 & 90.13 & 50.11 & 14.75 & 60.81 & 10.28 \\
\hline $\begin{array}{l}\mathrm{h}-\text { Maximum body depth } \\
\text { (last depth of caudal penducle) }\end{array}$ & 50.30 & 17.00 & 90.35 & 30.20 & 20.23 & 40.34 & 20.68 & 00.31 \\
\hline 1A - Length of pectoral fin & 60.80 & 24.00 & 12.78 & 40.56 & 20.85 & 60.56 & 30.66 & 00.56 \\
\hline hA - Depth of anal fin & 10.30 & 40.90 & 21.05 & 80.06 & 40.58 & 10.25 & 50.95 & 00.80 \\
\hline pl1 - Length of caudal penducle & 20.90 & 80.70 & 39.67 & 14.55 & 90.84 & 21.60 & 11.29 & 10.62 \\
\hline
\end{tabular}


Atlantic sturgeon Acipenser oxyrinchus and alien sturgeon species in Polish waters...

\begin{tabular}{|c|c|c|c|c|c|c|c|c|}
\hline 1 & 2 & 3 & 4 & 5 & 6 & 7 & 8 & 9 \\
\hline $\begin{array}{l}\text { pl2 - Distance from anal fin tip to tip } \\
\text { of middle rays in caudal fin }\end{array}$ & 33.60 & 117.30 & 58.79 & 20.58 & 14.98 & 29.92 & 16.80 & 10.98 \\
\hline 1V - Length of ventral (pelvic) fin & 10.20 & 39.10 & 20.88 & 70.75 & 40.42 & 11.23 & 50.94 & 00.96 \\
\hline $\begin{array}{l}\text { VA - distance from ventral fin base } \\
\text { to anal fin base }\end{array}$ & 17.50 & 83.30 & 35.63 & 15.39 & 70.54 & 22.13 & 10.10 & 20.36 \\
\hline $\begin{array}{l}\text { PV - Distance from pectoral fin base } \\
\text { to ventral fin base }\end{array}$ & 61.70 & 208.30 & 104.13 & 36.23 & 24.40 & 54.92 & 29.80 & 30.95 \\
\hline $\mathrm{aV}$ - Preventral distance & 117.50 & 363.60 & 193.41 & 63.10 & 52.19 & 98.36 & 55.59 & 60.35 \\
\hline $\mathrm{aA}$ - Predeorsal distance & 138.10 & 434.90 & 232.10 & 76.54 & 62.43 & 118.85 & 66.64 & 70.72 \\
\hline SRC - Width of snout at base of barbels & 13.40 & 33.90 & 21.30 & 60.04 & 40.84 & 90.96 & 60.24 & 00.97 \\
\hline 11 - Length of barbel & 80.20 & 24.00 & 13.33 & 30.68 & 30.08 & 90.73 & 30.98 & 10.08 \\
\hline $\begin{array}{l}\text { rc }- \text { Distance from tip of snout } \\
\text { to cartilaginous arch of mouth }\end{array}$ & 12.90 & 55.90 & 31.18 & 90.40 & 50.32 & 15.57 & 90.08 & 10.46 \\
\hline $\begin{array}{l}\text { rl-Distance from tip of snout to middle } \\
\text { barbel }\end{array}$ & 12.00 & 36.80 & 19.85 & 60.64 & 40.93 & 10.12 & 50.70 & 00.72 \\
\hline $\begin{array}{l}\text { rr - Distance from tip of barbel } \\
\text { to cartilaginous arch of mouth }\end{array}$ & 28.50 & 91.30 & 51.02 & 15.22 & 12.02 & 25.57 & 14.83 & 10.89 \\
\hline SO - Width of mouth & 80.70 & 28.60 & 15.06 & 40.61 & 30.27 & 70.17 & 40.37 & 00.55 \\
\hline $\begin{array}{l}\text { SRr }- \text { Width of snout at the base } \\
\text { of mouth }\end{array}$ & 15.30 & 46.70 & 27.09 & 80.17 & 50.45 & 13.36 & 70.90 & 10.21 \\
\hline iO - Interorbital distance (skull width) & 13.50 & 43.50 & 22.52 & 70.27 & 50.68 & 10.98 & 60.49 & 00.71 \\
\hline $\mathrm{BC}$ - Maximum width of head & 19.50 & 64.00 & 33.20 & 11.34 & 80.16 & 16.39 & 90.54 & 10.21 \\
\hline $1 \mathrm{P}-$ Length of pectoral fin & 24.10 & 46.80 & 30.52 & 60.89 & 90.95 & 12.88 & 11.39 & 00.70 \\
\hline
\end{tabular}

Table 3. Countable morphological characters of Acipenser oxyrinchus

\begin{tabular}{|l|c|c|c|c|}
\hline \multicolumn{1}{|c|}{ Character } & Min & Max & Mean & sd \\
\hline Number of dorsal scutes & 9 & 12 & 10.28 & 0.67 \\
\hline Number of lateral scutes & 21 & 30 & 25.22 & 1.76 \\
\hline Number of ventral scutes & 7 & 10 & 8.56 & 0.67 \\
\hline Number of dorsal fin rays & 28 & 41 & 36.46 & 2.46 \\
\hline Number of anal fin rays & 22 & 29 & 24.30 & 1.45 \\
\hline
\end{tabular}

The characters showed a low variation range. In order to reduce the signal and the number of characters for further comparison, principal component analysis (PCA) was conducted for the 21 measurable characters of the 4 sturgeon species. The value of $\chi^{2}$ was high (cumulative inertia: 0.999, $\chi^{2}=6,304.226, P=0.000$ ), which indicated that the species differed substantially with respect to measurable characters. Figure 2 shows distribution and direction of vectors on the graph depicted by the first two principal components of 21 morphological variables. 


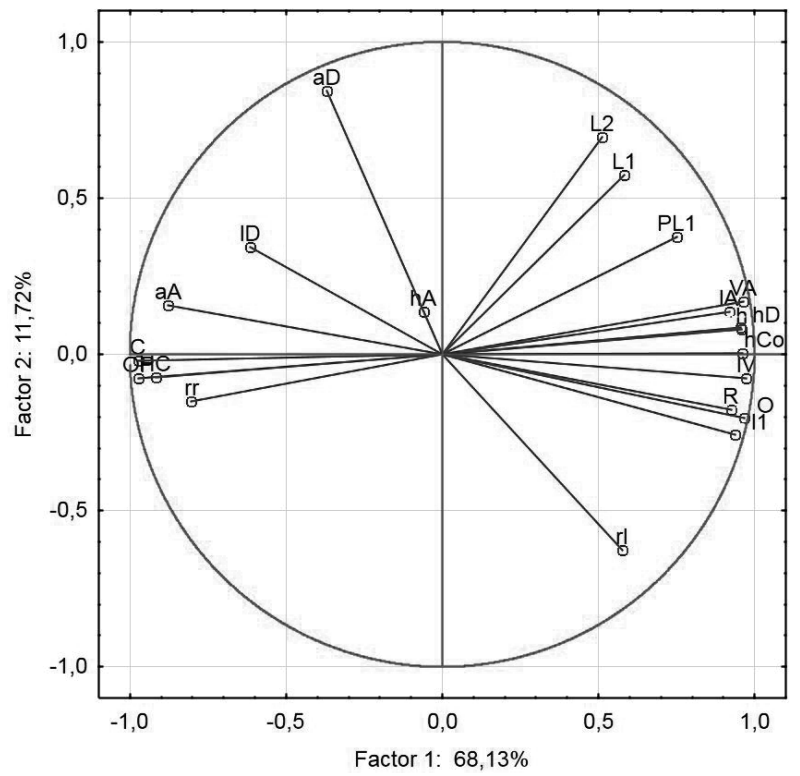

$\mathrm{R}$ - Preorbital distance (length of snout), LF- Fork length, LS- Standard length, C - Length of head, O - Horizontal eye diameter, $\mathrm{OP}$ - Postorbital distance, $\mathrm{HCo}$ - Head depth (at centre of eye), HC - Head depth (at nape), aD - Predorsal distance, $1 \mathrm{D}$ - Length of dorsal fin, Hd - Depth of dorsal fin, h - Maximum body depth (last depth of caudal penducle), 1A - Length of pectoral fin, hA - Depth of anal fin, P11 - Length of caudal penducle, 1V - Length of ventral (pelvic) fin, VA - distance from ventral fin base to anal fin base, aA - Preanal distance, 11 - Length of barbell, rl - Distance from tip of snout to middle barbell, $\mathrm{rr}$ - Distance from tip of barbel to cartilaginous arch of mouth.

Figure 2. Results of the principal component analysis for measurable characters with the highest contribution to species differentiation. Projection of the variables on the factor-plane $(1 \times 2)$

The PCA revealed that the measurable characters with the highest contribution to differentiation of the 4 sturgeon species included head characters along with distance from ventral fin base to anal fin base (VA) and length of ventral (pelvic) fin (IV). Characters with the highest contribution to the first two principal components were selected for stepwise discriminant analysis. All compared measurable characters were taken into account in the discriminant function model (Wilks' lambda: 0.00014 approx. F $(27.2065)=1,512.9 P<0.0000)$. A classification matrix for the stepwise discriminant analysis generated for nine measurable characters of the species was characterized by a high level of correctness (99.5828\% Table 4).

The classification matrix displayed the lowest correctness for A. oxyrinchus and A. stellatus, and the highest for $A$. baerii and $A$. gueldenstaedtii. Only individual specimens of $A$. oxyrinchus might be incorrectly classified as $A$. stellatus or $A$. gueldenstaedtii (Table 4). On the basis of both discriminant functions, canonical discriminant analysis clearly discriminated the four species with respect to their biometric characters (Figure 3). 
Table 4. Classification matrix of the stepwise discriminant analysis for measurable characters of four sturgeon species, rows: observed classification; columns: expected classification

\begin{tabular}{|l|c|c|c|c|c|}
\cline { 2 - 6 } \multicolumn{1}{c|}{} & \% correct & $\begin{array}{c}\text { Acipenser } \\
\text { oxyrinchus } \\
P=0.06815\end{array}$ & $\begin{array}{c}\text { Acipenser } \\
\text { gueldenstadtii } \\
P=0.37691\end{array}$ & $\begin{array}{c}\text { Acipenser } \\
\text { baerii } \\
P=0.46453\end{array}$ & $\begin{array}{c}\text { Acipenser } \\
\text { stellatus } \\
P=0.09040\end{array}$ \\
\hline A. oxyrinchus & 95.9184 & 47 & 1 & 0 & 1 \\
\hline A. gueldenstadtii & 100.0000 & 0 & 271 & 0 & 0 \\
\hline A. baerii & 100.0000 & 0 & 0 & 334 & 0 \\
\hline A. stellatus & 98.4615 & 1 & 0 & 0 & 64 \\
\hline Total & 99.5828 & 48 & 272 & 334 & 65 \\
\hline
\end{tabular}

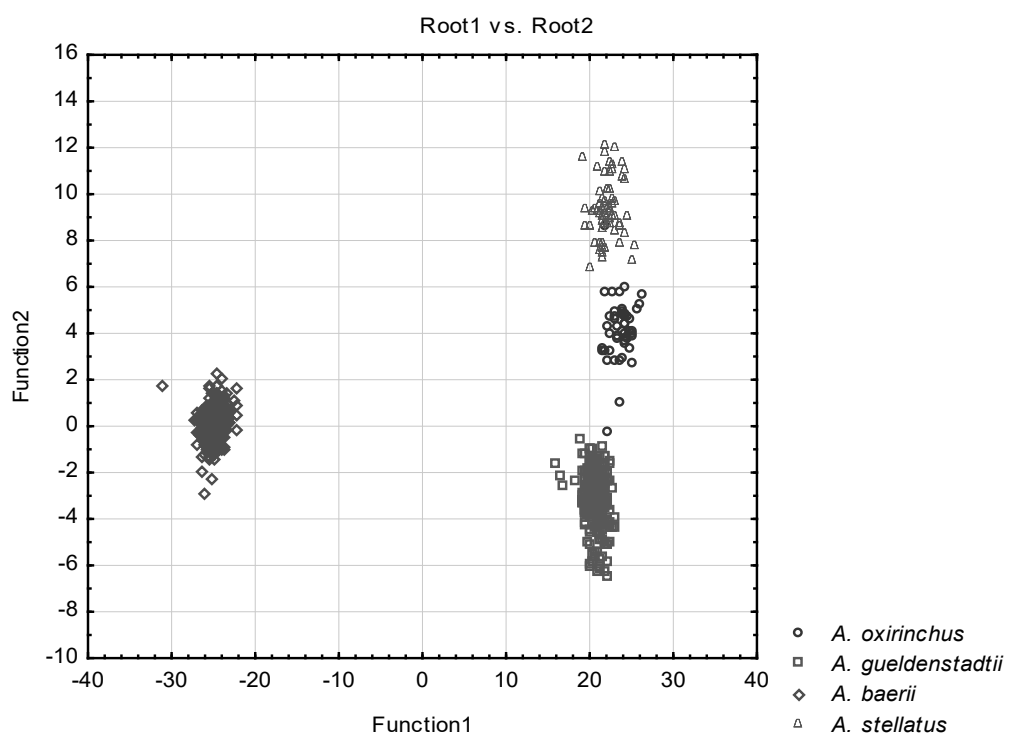

Figure 3. Scatter plot of canonical scores for the analysis of measurable characters of the 4 sturgeon species (root 1; root 2)

The first discriminant function separated $A$. gueldenstaedtii, A. oxyrinchus, A. stellatus, and $A$. baerii. The second function discriminated between $A$. oxyrinchus and $A$. gueldenstaedtii and also between $A$. stellatus and $A$. gueldenstaedtii. According to the position of $A$. baerii on the graph, the second function situate this species between $A$. oxyrinchus and A. gueldenstaedtii. In the first function (root 1), character VA made the most significant contribution to discrimination, while, in the second function (root 2), the significantly contributing characters included horizontal eye diameter and preorbital distance. Postorbital distance had a significant contribution only in the first function (Table 5, Figure 4). 
Table 5. Standardized coefficients for canonical variables of measurable characters, Root1-3 - classification functions

\begin{tabular}{|l|r|r|r|}
\cline { 2 - 4 } \multicolumn{1}{c|}{} & Root 1 & Root 2 & Root 3 \\
\hline OP & 0.6763 & -0.43705 & 0.10452 \\
\hline HCo & -0.5037 & -0.70146 & 0.17790 \\
\hline R & -0.3309 & 2.31381 & 1.03342 \\
\hline O & -0.7311 & -2.71539 & 1.55823 \\
\hline VA & -0.8352 & -0.04078 & 0.21091 \\
\hline 11 & 0.1216 & 1.03025 & -2.47056 \\
\hline HC & 0.4408 & 0.37853 & 0.21382 \\
\hline C & 0.3019 & 0.00752 & 0.31132 \\
\hline IV & -0.2852 & -0.13161 & -0.05984 \\
\hline Eigenvalue & 336.0406 & 9.75159 & 0.94491 \\
\hline Cumulative per cent & 0.9692 & 0.99727 & 1.00000 \\
\hline
\end{tabular}

OP - Postorbital distance; $\mathrm{HCo}$ - Head depth; R - Preorbital distance; O - Horizontal eye diameter; VA - Distance from ventral fin base to anal fin base; 11 - Length of barbell; HC - Head depth; C - Length of head; IV - Length of ventral (pelvic) fin.

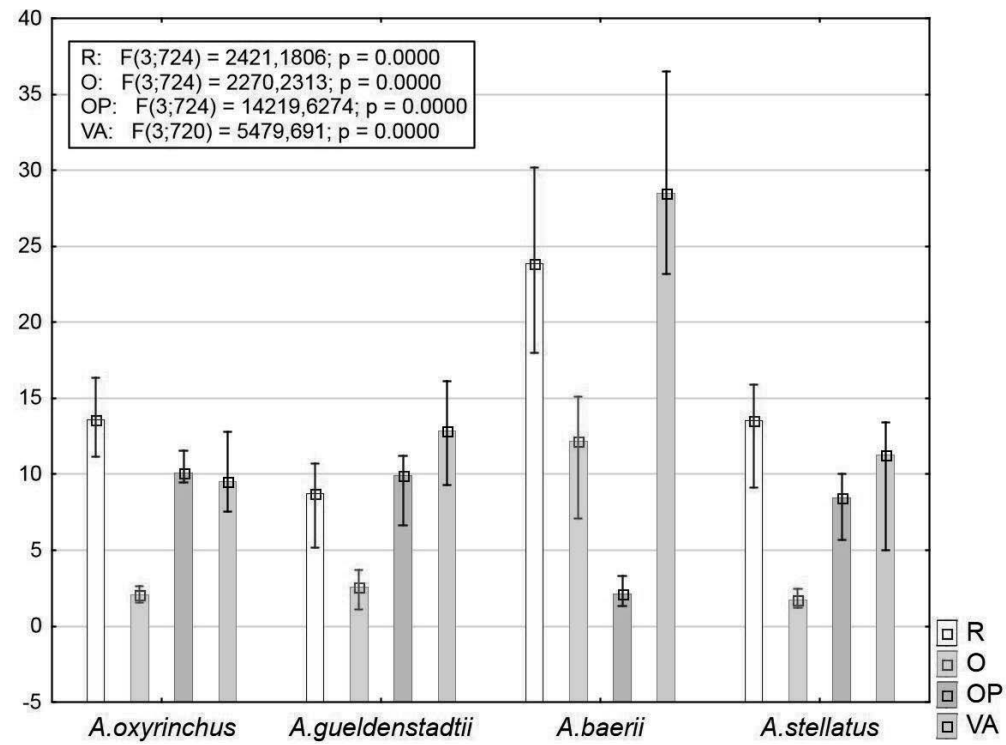

VA - distance from ventral fin base to anal fin base, $\mathrm{R}$ - Pre-orbital distance (length of snout), $\mathrm{O}$ - Horizontal eye diameter, OP -Postorbital distance.

Figure 4. Comparison of the median values of characters providing the greatest contribution to discriminant functions for the 4 sturgeon species 


\section{Countable Characters}

The analysis of standardized coefficient values for canonical variables indicated number of lateral scutes as the character with the most significant contribution to discrimination (Table 6).

Table 6. Standardized coefficients for canonical variables of countable characters, Root 1 - first classification function; Root 2 - second classification function

\begin{tabular}{|l|c|c|c|}
\cline { 2 - 4 } \multicolumn{1}{c|}{} & Root 1 & Root 2 & Root 3 \\
\hline SL & 0.941708 & -0.095766 & -0.517779 \\
\hline SV & -0.092696 & 1.007434 & -0.054934 \\
\hline SD & 0.163372 & 0.049238 & 1.054514 \\
\hline Eigenvalue & 6.258933 & 0.324818 & 0.000476 \\
\hline Cumulative per cent & 0.950595 & 0.999928 & 1.000000 \\
\hline
\end{tabular}

SL - Number of lateral scutes, SV - Number of ventral scutes, SD - Number of dorsal scutes.

Correctness of the classification matrix for countable characters was calculated as $79.92 \%$, lower than for measurable characters (Table 7).

Table 7. Classification matrix of the stepwise discriminant analysis for countable characters of four sturgeon species, rows: observed classification; columns: expected classification

\begin{tabular}{|l|c|c|c|c|c|}
\hline \multicolumn{1}{|c|}{ Species } & \% correct & $\begin{array}{c}\text { A. oxyrinchus } \\
P=0.09042\end{array}$ & $\begin{array}{c}\text { A. baerii } \\
P=0.60579\end{array}$ & $\begin{array}{c}\text { A. gueldenstaedtii } \\
P=0.17902\end{array}$ & $\begin{array}{c}\text { A. stellatus } \\
P=0.12477\end{array}$ \\
\hline A. oxyrinchus & 98.00 & 49 & 0 & 0 & 1 \\
\hline A. baerii & 96.72 & 0 & 324 & 9 & 2 \\
\hline A. gueldenstaedtii & 7.07 & 0 & 92 & 7 & 0 \\
\hline A. stellatus & 89.86 & 7 & 0 & 0 & 62 \\
\hline Total & 79.93 & 56 & 416 & 16 & 65 \\
\hline
\end{tabular}

In spite of there being relatively fewer $A$. oxyrinchus, $98 \%$ of $A$. oxyrinchus individuals were correctly discriminated. The highest possibility of an error based on countable characters was observed for A. gueldenstaedtii, which showed similarity of meristic characters with A. baerii, as well as the distinctiveness of the $A$. oxyrinchus from other species on the basis of having significantly fewer lateral scutes (Figure 5). 


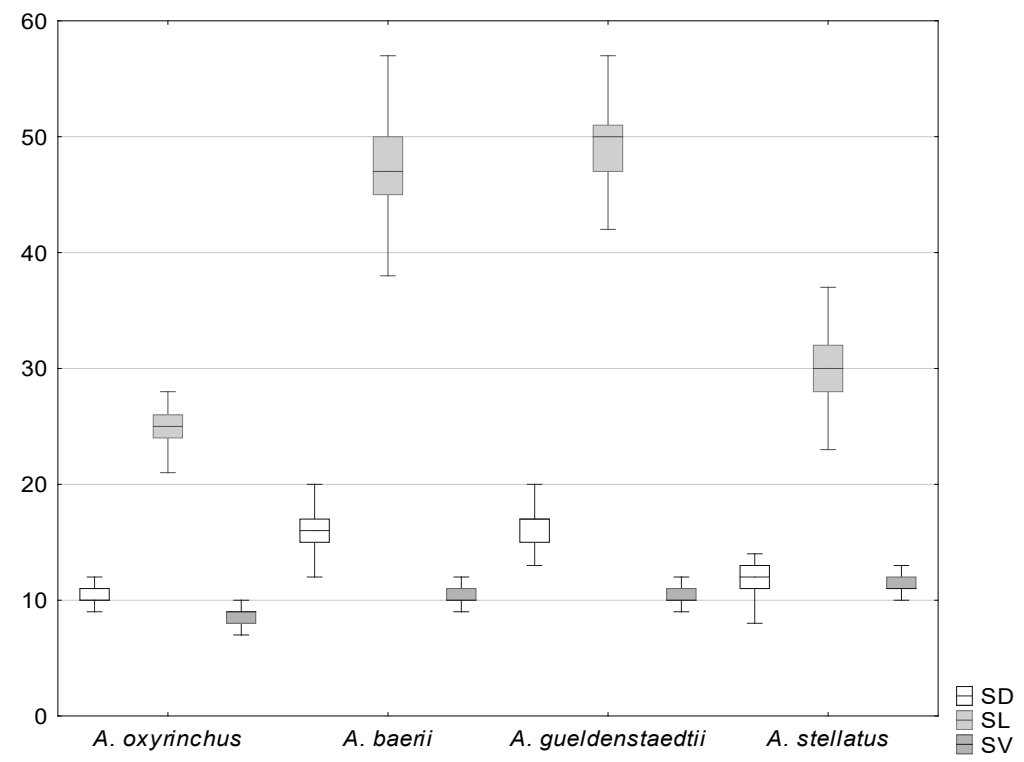

Figure 5. Median values of countable characters: number of dorsal scutes, number of lateral scutes and number of ventral scutes in four sturgeon species

\section{Discussion}

The data from the present study may be used to supplement existing systematic keys and lay the foundations for creating a catalogue or atlas of popular species and interspecific hybrids of sturgeon, including their complete systematic determination (Krylova, 1997). Correct identification is especially important in the context of species restoration. Stocking of juvenile European sea sturgeon and A. oxyrinchus as part of their re-establishment programme in Europe (Elvira, Gessner, 1996; Gessner et al., 2010) along with the co-occurrence of alien species, requires an informational campaign for users of the waters, focusing on distinguishing between native and non-native species. A reference book containing a simple and user-friendly key with sound taxonomic data is necessary. The data available for comparison with the results of the present biometric analyses were conducted on only a small number of living specimens (Artiukhin, Vecsei, 1999; Debus, 1999). When examining 27 museum specimens and a single live sturgeon, it was noted that variability of some characters of the sturgeon head, mainly due to scraping the substratum while feeding, precluded considering distances connected with snout structure as distinguishing characteristics. Comparison of dorsal and lateral scutes suggested that A. oxyrinchus differs from A. sturio from the Gironde (Atlantic Ocean) and the Rioni (Black Sea) rivers (Ninua, 1976). The analyses discussed in the present paper compared morphometric data of $A$. oxyrinchus, A. stellatus, A. gueldenstaedtii, and A. baerii. Among measurable characters expressed as per cent of $L_{\mathrm{T}}$, preorbital distance, distance from ventral fin base to anal fin base (VA), horizontal eye diameter (O), and postorbital distance (OP) had the highest contribution to discrimination (Figure 4). Mainly on the basis of VA, the first function clearly discriminated 
between $A$. baerii and those of $A$. oxyrinchus, A. gueldenstaedtii, and A. stellatus (Figure 3). A longer VA distance distinguished $A$. baerii from the other three sturgeon species (Figure 4). In the second function, preorbital distance contributed significantly to discrimination due to the positive value of the canonical variable coefficient; whereas, in the second function, horizontal eye diameter contributed significantly to discrimination (Table 5). On the basis of this analysis it can be concluded that the shorter the rostrum of an A. oxyrinchus individual, the higher the possibility of mistaking it for $A$. gueldenstaedtii. Distinguishing $A$. oxyrinchus from $A$. baerii may present difficulties due to considerable changes of the rostrum length during the lifetime of the latter, as well as the existence of short-rostrum and long-rostrum forms of A. baerii (Keszka et al., 2009). Thus, the risk of an erroneous classification is high in the case of juvenile A. baerii individuals, which have a longer rostrum than adults of the species. The risk of mistaking $A$. oxyrinchus for another species on the basis of measureable characters is the highest with respect to $A$. stellatus. The second classification function, with rostrum length having the major contribution to discrimination, clearly distinguished between the $A$. gueldenstaedtii and $A$. baerii grouping and the $A$. stellatus and $A$. oxyrinchus grouping while the first classification function separated the group of $A$. baerii from the groups of the remaining three sturgeon species.

Based on the five analysed countable characters, exotic species are clearly distinguishable from A. oxyrinchus. The number of lateral scutes had the highest contribution to discrimination (Table 6). In the sample, the number of scutes ranged from 21 to 30, with a mean of 25.22. The value was lower than that observed for $A$. oxyrinchus in the St Lawrence River in Canada (28.67) (Artiukhin, Vecsei, 1999) and considerably lower than found for exotic species occurring in Polish waters (Keszka, Heese, 2003; Keszka, Krzykawski, 2008; Keszka et al., 2009). Low variability of the countable characters in A. oxyrinchus specimens in the present study might be due to the limited number of broodstock used to produce stocking material as well as to an effect of artificial rearing conditions on juvenile fish, as had been noted in the case of other cultured sturgeon species (Ruban, Sokolov, 1986).

Exotic sturgeon introduction into European waters may occur from fish released by aquarium owners and hobbyists who want to dispose of large individuals, sturgeons intentionally released by fishing clubs and associations, and accidental escape from ponds and farms. Despite clear regulations applying to alien species in aquaculture under the European Commission Regulation (EC) no. 535/2008 of 13 June 2008 rules for implementation of the Council Regulation (EC) no. 708/2007 concerning use of alien and locally absent species in aquaculture, a fourth source of exotic sturgeon introduction involves artificial breeding and release (Britton, Davis, 2006). The occurrence of non-native sturgeon species in German and Polish coastal waters and river estuaries has been growing since the beginning of the 1990s (Spratte, Rosenthal, 1996; Keszka, Stepanowska, 1997; Arndt et al., 2000, 2002; Keszka, Heese, 2003; Keszka et al., 2011). The presence of exotic sturgeon species was also observed in the Gironde River in France in 1999 after a period of storms that caused water levels to rise and resulted in the escape of several thousand A. baerii from fish farms. This presented a serious problem for inland fishers and anglers in distinguishing between two sturgeon species, of which one (A. sturio) was strictly protected and the second (A. baerii) needs to be eliminated from open waters (Gessner et al., 2010). Alien species release, taking place in spite of the prohibitions connected with environmental protection, should be considered a potential threat, since alien species may have a negative effect on native species and their populations, especially in strongly altered ecosystems (Leppäkoski et al., 2002).

Apart from the above implications for alien species introduction, genetic implications cannot be dismissed, as sturgeons display a potential for hybridization (Kozhin, 1964). Current 
information suggests that the hybrids are fertile, which means that mixed genetic material is passed on to the next generation, resulting in a dispersal of the original genetic information and reducing adaptation ability to habitats. The existence of the first hybrids created as a result of release of exotic $A$. baerii has been confirmed by genetic analyses conducted on specimens collected from the Danube River (Ludwig et al., 2009).

Avoidance of loss connected with fisheries is an important principle behind protecting the remaining native populations in situ (Kapusta et al., 2008), Gessner et al., 2010), Key factors in effective restoration of a population include decreasing fishing-associated mortality and obtaining a high level of acceptance and support from the fishery sector. Measures that need to be taken include instituting and monitoring programs to limit accidental catch based on the ability of fishers to identify species. The example of $A$. sturio in France and preliminary results obtained from Germany clearly show that this is possible (Gessner et al., 2010).

\section{References}

Arndt, G.M., Gessner, J., Anders, E., Spratte, S., Filipiak, J., Debus, L., Skóra, K. (2000). Predominance of exotic and introduced species sturgeons among sturgeons captured from the Baltic and North Seas and their watersheds, 1981-1999. Boletin del Instituto Espanol de Oceanografia, 16, 29-36.

Arndt, G.M., Gessner, J., Raymakers, C. (2002). Trends in farming, trade and occurrence of native and exotic sturgeons in natural habitats in Central and Western Europe. Journal of Applied Ichthyology, $18,444-448$.

Artyukhin, E., Vecsei, P. (1999). On the status of Atlantic sturgeon: Conspecificity of European Acipenser sturio and North American Acipenser oxyrinchus. Journal of Applied Ichthyology, 1-5, 35-37.

Britton, J.R., Davies, G.D. (2006). Ornamental species of the genus Acipenser: new additions to the ichthyofauna of the UK. Fisheries Management and Ecology, 13, 207-210.

Debus, L. (1999). Meristic and morphological features of the Baltic sturgeon (Acipenser sturio L.). Journal of Applied Ichthyology, 15, 38-45.

Elvira, B., Almodovar, A. (1997). A morphological study of the native sturgeon Acipenser sturio from Spain, and recent records of the exotic Siberian sturgeon A. baerii. In: P. Bronzi, D.J. McKenzie, G. DeCati, R. Rossi (eds.), Proceedings of the 3rd International Symposium on Sturgeon. Berlin: Blackwell Wissenschafts-Verlag.

Elvira, B., Gessner, J. (1996). The Society to Save the Sturgeon Acipenser sturio. The Sturgeon Quarterly, $4,7$.

Filipiak, J. (1996). Occurence of sturgeon fish in the Odra River estuary. In: J. Filipiak (ed.), Present problems of fish stock management in Polish and German parts of Pomeranian Bay and Szczecin Lagoon (pp. 17-18). Świnoujście: Sea Fisheries Institute.

Gessner, J., Debus, L., Filipiak, J., Spratte, S., Skóra, K.E., Arndt, G.M. (1999). Development of sturgeon catches in German and adjacent waters since 1980. Journal of Applied Ichthyology, 15, 136-141.

Gessner, J., Friedrich, F., Migdalska, B., Domagała, J., Bartel, R. (2008). Untersuchungen zu Wanderbewegungen juveniler Stoere (Acipenser oxyrinchus) im Oder- (Odra-) Einzugsgebiet. NationalparkJahrbuch. Criewen.

Gessner, J., Tautenhahn, M., von Nordheim, H., Borchers, T. (2010). Nationaler Aktionsplan zum Schutz und zur Erhaltung des Europäischen Störs (Acipenser sturio). Berlin: BMU/BfN (Hrg.).

Grabda, E. (1971). Jesiotr - żywy zabytek przyrody. Przyroda Polska, 1, 10-11. 
Guénette, S., Fortin, R., Rassart, E. (1993). Mitochondrial DNA Variation in Lake sturgeon (Acipenser fulvescens) from the St. Lawrence River and James Bay Drainage Basins in Quebec, Canada. Canadian Journal of Fisheries and Aquatic Sciences, 50, 659-664.

Kapusta, A., Duda, A., Kolman, R. (2008). Movements of juvenile Atlantic sturgeon, Acipenser oxyrhynchus Mitchill, in the Drwęca River (central Poland). In: R. Kolman, A. Kapusta (eds.) Actual status and active protection of sturgeon fish populations endangered by extinction. Olsztyn: IRS.

Kempter, J., Sadowski, J., Schütze, H., Fischer, U., Dauber, M., Fichtner, D., Panicz, R., Bergmann, S.M. (2009). Koi Herpes Virus: Do acipenserid restitution programs pose a threat to carp farms in the disease-free zone? Acta Ichthyologica et Piscatoria, 39, 119-126.

Kempter, J., Hofsoe, P., Neumann, A., Panicz, R., Keszka, S. (2013). Intra and inter-stock variability in sterlet (Acipenser ruthenus) as assessed with biometric and genetic analyses. EJPAU 16 (3), \#01.

Keszka, S., Heese, T. (2003). Occurrence of exotic Russian sturgeons, Acipenser gueldenstaedtii Brandt et Ratzeburg, 1833 (Actinopterygii: Acipenseridae) in the Baltic Sea. Acta Ichthyologica et Piscatoria, $33,183-178$.

Keszka, S. (2000). Zmienność cech biometrycznych młodzieży ryb jesiotrowatych (Acipenseridae) w warunkach akwakultury na przykładzie jesiotra rosyjskiego (Acipenser gueldenstaedtii Brandt, 1833) i leńskiego jesiotra syberyjskiego (Acipenser baerii stenorrhynchus Nikolski, 1896). PhD thesis. Szczecin: AR.

Keszka, S., Raczyński, M. (2006). Cechy biometryczne młodzieży siewrugi Acipenser stellatus Pallas, 1771, podchowanej w kanale ciepłym elektrowni "Dolna Odra". XX Zjazd Hydrobiologów Polskich 5-8.09.2006 (p. 120).

Keszka, S., Krzykawski, S. (2008). Morphometry of juvenile Russian Sturgeon (Acipenser gueldenstaedtii Brandt et Ratzeburg, 1833) from fish farms. Acta Scientiarum Polonorum. Piscaria, 7, 21-36.

Keszka, S., Krzykawski, S., Więcaszek, B. (2009). Variability of biometric characters of Acipenser baerii Brandt, 1869 in the heated water aquaculture. Electronic Journal of Polish Agricultural Universities, $12,23$.

Keszka, S., Stepanowska, K. (1997). Pojawienie się jesiotrów (Acipenseridae) w estuarium Odry. Komunikaty Rybackie, 2, 11-12.

Keszka, S., Tański, A., Pender, R., Potkański, Ł., Czerniejewski, P. (2011). Identification of threats to biodiversity on the basis of an analysis of the ichthyofauna in Głębokie Lake in the city of Szczecin. In: M. Jankun, G. Furgała-Selezniow, M. Woźniak, A.M. Wiśniewska Water (eds.), Biodiversity assessment and protection (pp. 147-154). Olsztyn: UWM.

Kolman, R., Kapusta, A., Szczepkowski, M., Duda, A., Bogacka-Kapusta, E. (2008). Jesiotr bałtycki Acipenser oxyrhynchus oxyrhynchus Mitchill. Olsztyn: IRŚ.

Kolman, R., Kapusta, A., Duda, A. (2011a). Re-establishing the Atlantic Sturgeon (Acipenser oxyrinchus oxyrinchus Mitchill) in Poland. In: P. Williot, E. Rochard, N. Desse-Berset, F. Kirschbaum, J. Gessner, (eds.) Biology and conservation of the European sturgeon Acipenser sturio L. 1758 (pp. 573-581). Berlin Heidelberg: Springer-Verlag.

Kolman, R., Kapusta, A., Duda, A., Wiszniewski, G. (2011b). Review of the current status of the Atlantic sturgeon Acipenser oxyrinchus oxyrinchus Mitchill 1815, in Poland: principles, previous experience, and results. Journal of Applied Ichthyology, 27, 186-191.

Kozhin, N.I. (1964). Osetrovye SSSR i ikh vosproizvodstvo. Trudy VNIRO, 52, 21-58.

Krylova, V.D. (1997). On the problem of universal methodology of morphological analysis of sturgeons (Acipenseridae). In: P. Bronzi, D.J. McKenzie, G. DeCati, R. Rossi (eds.) Proceedings of the 3rd International Symposium on Sturgeon. Berlin: Blackwell Wissenschafts-Verlag.

Kulmatycki, W. (1919). Galicja Wschodnia i rybactwo. Przeglad Rybacki, 2, 27. 
Kulmatycki, W. (1921). Rybactwo na Śląsku. Rybak Polski, 17, 141-143.

Kulmatycki, W. (1922). Rybactwo na Podolu. Rybak Polski, 17, 285-288.

Kulmatycki, W. (1932). W spawie zachowania jesiotra w rzekach polskich. Ochrona Przyrody, 12, 1-21.

Kulmatycki, W. (1933). W sprawie zachowania jesiotra Acipenser sturio L. w rejonie ujścia Odry. Przegląd Zoologiczny, 11, 149-151.

Leppakoski, E., Gollasch, S., Olenin, S. (2002). Invasive aquatic species of Europe. Distribution, impact and management. Dordrecht: Kluwer Academic Publishers.

Loy, A., Molteni, S., Bronzi, P. (1997). Geometric in the characterisation of the cranial growth pattern of Acipenser naccari. In: P. Bronzi, D.J. McKenzie, G. DeCati, R. Rossi (eds.), Proceedings of the 3rd International Symposium on Sturgeon. Berlin: Blackwell Wissenschafts-Verlag.

Ludwig, A., Debus, L., Lieckfeld, D., Wirigin, I., Benecke, N., Jenneckens, I., Willot, P., Waldmann, J.R., Pitra, C. (2002). When the American sea sturgeon swam east. Nature, 419, 447-448.

Ludwig, A., Lippold, S., Debus, L., Reinartz, R. (2009). First evidence of hybridization between endangered sterlets (Acipenser ruthenus) and exotic Siberian sturgeons (Acipenser baerii) in the Danube River. Biological Invasions, 11, 753-760.

Maury-Brachet, R., Rochard, E., Durrieu, G., Boudou, A. (2008). The Storm of the Century' (December 1999) and the Accidental Escape of Siberian Sturgeons (Acipenser baerii) into the Gironde Estuary (Southwest France). An original approach for metal contamination. Environmental Science and Pollution Research, 15, 89-94.

Nabiałek, J. (1974). Jesiotry w Wiśle. Gospodarstwo Rybackie, 1, 10.

Ninua, N.S.H. (1976). Atlanticeskij osetr reki Rioni. Tbilisi: Izdatel'stvo Metsniereba.

Paaver, T. (1997). Distribution of native and introduced species of sturgeons in Estonia. In: P. Bronzi, D.J. McKenzie, G. DeCati, R. Rossi (eds.), Proceedings of the 3rd International Symposium on Sturgeon. Berlin: Blackwell Wissenschafts-Verlag.

Ruban, G.I., Panaiotidi, A.I. (1994). Sravnitelnyj analiz podvidov sibirskovo osetra Acipenser baeri stenorrhynchus i A. baeri chatys (Acipenseridae) rek Jenisej i Lena. Voprosy Ichtiologii, 34, 469-478.

Ruban, G.I., Sokolov, L.I. (1986). Morfologiceskaâ izmenčivost sibirskogo osetra Acipenser baeri Brandt reki Lena v svazi s vyraŝivaniem ego na teplyh vodah. Voprosy Ichtiologii, 26, 470-475.

Sasorski, M. (1922). O połowach łososia i jesiotra w Wiśle pod Krakowem. Rybak Polski, 20-21, 346-347.

Spratte, S., Rosenthal, H. (1996). Meldungen uber Storfange im Einzugsbereich der deutschen Nordseekuste (1981-1985). Fischer und Teichwirt, 47, 78-82.

Starkiewicz, L. (1922). Rybołówstwo na Dniestrze. Rybak Polski, 23, 385-387.

Żelechowska, J. (1964). Jesiotr w Wiśle koło Torunia. Gospodarstwo Rybackie, 8, 6-7.

Cite as: Keszka, S., Panicz, R. (2018). Atlantic sturgeon Acipenser oxyrinchus and alien sturgeon species in Polish waters: can biometric analysis assist species discrimination and restoration? Acta Biologica, 25, 5-18. DOI: 10.18276/ab.2018.25-01. 